\title{
SOCIOECONOMIC STATUS OF PARENTS AND THE ACHIEVEMENT OF CHILDREN ON READINESS FOR SCHOOL TESTS
}

Anela Hasanagić, International Univeristy of Sarajevo, Bosnia and Herzegovina.

\section{Abstract}

This article examines whether socio-economic status and geographic location impact children on readiness for school tests in Bosnia and Herzegovina. The sample used in this study consisted of 296 children: approximately half of the children were from rural areas and the other half from urban areas in Bosnia and Herzegovina. Tests that were used included: Differences test, Similarities test, Numerical test, Trace test, Knowledge Test, Questionnaire for measuring socio-emotional maturity, and Goodenough's Draw-a-Man Test. Results show that there are statistically significant differences between children from different socio-economic background on these tests. Children whose parents are low educated have lower results on Readiness for school test, compared to children whose parents have finished high school or college. The results showed that geographic location was not as significant a factor in readiness for school tests. There were differences between village and town children only on Goodenough's Draw-a-Man Test and on Similarity test, while on other tests showed no significant correlation between this variable.

Keywords: socio-economic status, socio-demographic characteristics, readiness for school, academic achievement. 


\section{Introduction}

Socioeconomic status is an important factor in many aspects of living as in academic achievement as well. Many researchers have shown that there is a correlation between academic achievement of parents and academic achievement of their children. (Brody, Stoneman and Florr, 1995) According to Papalia and Olds, more educated parents were more involved in education of their children, and they also had higher income. Families with higher income have tendency for higher rate of support and concordance. Children are raised in positive atmosphere; their mothers show the support and are willing to help in achievement, and those children tend to develop better self-regulation, and also to have better academic achievement.

Luster and McAdoo found that academic achievement is not determined by socioeconomic status by itself, but socioeconomic status impacts on family, and that family structure and support is important factor for academic achievement. (Luster and McAdoo, 1996) They did a longitudinal study among Afro-American children who live in poor families. They found differences among these children in terms of family support structure. Children with stronger support networks had higher IQ's, were more motivated, and at the same time they had mothers who were more educated and interested in cooperation with teachers.

Rothenberg (1969) discovered obvious differences in conservation among children from different socioeconomic status. Horvat (1986), based on his research and similar research findings of Dolanc (1971) and Kolar (1971), concluded that there are differences among children from different socioeconomic status, from differently educated parents and that those differences are evident from the age of six or seven years, and that also, there are differences in school achievement among these groups of children whose parents are low or highly educated. Children whose parents are more educated are more motivated for further development; they have goals that help them to have higher achievement.

Residence is also important factor in academic achievement, Often with residence, one only considers the cultural differences among certain population. It was thought that some cultures (or subcultures) are more deficient compared to others. But, nowadays, we are more like to think about cultural differences in term of the differences that are result of living in certain life circumstances. In Bosnia and Herzegovina, we usually think about the context of residence, actually about the differences between children who live in village (rural) or in town (urban areas). Many of researches that have been done about this topic, Mandić and Gajanović (1982) showed that there are differences between children 
from towns and children from villages on tests of intelligence, and tests of academic achievement. In Bosnia and Herzegovina, because of these differences, we had different standards for measuring the readiness of urban and rural children.

Many things changed following the 1992-95 war in Bosnia and Herzegovina. Many people from rural areas moved to urban ones because of better educational and career opportunities. A lot of people from villages have college degees due to necessity. Also, rural areas are not like they used to be. Globalization now makes everything available in rural areas just like in more urban areas. Children in rural areas now have computers, internet, cable TV etc. Preschool children, go to kindergartens, and their parents are more educated. Considering those facts that took place over last twenty years, it is necessary to check whether different standards of testing children from villages and towns, and different expectations from children in school, are still valid, or it is safe to assume that children from urban and rural areas have the same potential for starting the elementary school.

\section{Hypothesis:}

H1. We hypothesize that children whose parents are highly educated will have statistically significant better results on the Readiness for School Tests.

H2. We Hypothesize that there are no statistically significant differences between children from urban and rural areas on Readiness for School Tests.

\section{Methodology}

This research was planned like combination of quasi-experimental and correlational research that included method of systematic observation.

\section{Participants:}

Thisstudy'sn-sizeconsisted296earlyelementaryschoolchildren:147 boysand 149girls.

Table 1. Frequencies of educational level of parents, according to the nomenclature of educational lever adopted in $\mathrm{BiH}$.

\begin{tabular}{|l|l|l|l|l|}
\hline & \multicolumn{2}{|c|}{ Father } & \multicolumn{2}{c|}{ Mother } \\
\hline & Frequencies & Percentage & Frequencies & Percentage \\
\hline NK (nonqualified) & 23 & 7,8 & 64 & 21,6 \\
\hline KV (qualified) & 39 & 13,2 & 33 & 11,1 \\
\hline $\begin{array}{l}\text { VKVhigh quali- } \\
\text { fied) }\end{array}$ & 47 & 15,9 & 20 & 6,8 \\
\hline SSS (high school) & 141 & 47,6 & 151 & 51,0 \\
\hline
\end{tabular}




\begin{tabular}{|l|l|l|l|l|}
\hline $\begin{array}{l}\text { VS (undergrad- } \\
\text { uate) }\end{array}$ & 22 & 7,4 & 18 & 6,1 \\
\hline VSS (graduate) & 18 & 6,1 & 8 & 2,7 \\
\hline $\begin{array}{l}\text { MR or DR (MA or } \\
\text { PhD) }\end{array}$ & 1 & 0,3 & - & - \\
\hline Total & 291 & 98,3 & 294 & 99,3 \\
\hline Missing & 5 & 1,7 & 2 &, 7 \\
\hline Total & 296 & 100 & 296 & 100 \\
\hline
\end{tabular}

Table 2. Frequencies of sample considering the residence as an independent variable.

\begin{tabular}{|l|l|l|}
\hline & \multicolumn{1}{|c|}{ Frequencies } & \multicolumn{1}{c|}{ Percentage } \\
\hline Urban & 149 & 50,3 \\
\hline Rural & 147 & 49,7 \\
\hline Total & 296 & 100,0 \\
\hline
\end{tabular}

\section{Instruments:}

For the purpose of this research, researcher used a battery of tests and a questionnaire for parents.

\section{Tests}

- Differences test - was taken from Thorndike's Modified test of intelligence, which was previously applied by Mandić and Gajanović (1971). In this instrument participants were asked to find the picture that is totally different from other pictures among the five pictures. The test has 12 items.

- $\quad$ Similarity test - was also taken from Thorndike's Modified test of intelligence, and which was previously applied by Mandić and Gajanović (1971). The participant needs to find two pictures that are similar to each other among five pictures. It has 11 items.

- $\quad$ Numerical test - the idea of this test is taken from research that was made by Vlahović-Štetić, et al. (1995), but some items are added, because of the measuring conservation of number. It measures conservation, counting, simple summarizing, ordinal numbers, half of something etc. It has 9 questions.

- $\quad$ Trace test - it measures the oculo-motor coordination and fine motor skills when mapping some objects. It has five items for evaluation. On each item, better drawing is evaluated, and it can be evaluated with 0,1 and 2 points. Maximum is 10 . Total score was calculated like simple linear combination of those four tests (sum of scores on Difference Test, Similarities Test, Numerical Test and Trace Test).

- Goodenough's'Draw-a-man” test - measures intelligence on children. It evaluates how many elements a child drowns on assignment: Draw a man!” 
- $\quad$ Knowledge test - measures the knowledge about colors, shapes, letters, reading and understanding the materials that is read. It has 6 parts, and maximum is 58 .

\section{Questionnaire}

- Questionnaire for parents - Socio-Emotional Questionnaire, which measures socio-emotional readiness for school, but also some socioeconomic facts about family. It has 37 items, and parents answered on questions.

\section{Procedure:}

The research was conducted in May 2011. For all children that were a part of research Informed Consent from parents was taken.

\section{Results}

Testing the statistical significant differences of achievement on Readiness for school tests considering the level of education of parents like the independent variable, by using the ANOVA for two independent variables.

Table 3. Intercept ANOVA with two independent variables (mother and father educational level) and dependent variables

\begin{tabular}{|l|l|l|l|l|l|l|}
\hline Source & $\begin{array}{l}\text { Dependent } \\
\text { Variable }\end{array}$ & $\begin{array}{l}\text { Type III Sum } \\
\text { of Squares }\end{array}$ & df & Mean Square & F & Sig. \\
\hline \multirow{4}{*}{$\begin{array}{l}\text { Correct-ed } \\
\text { Model }\end{array}$} & Difference Test & $254.471 \mathrm{a}$ & 12 & 21.206 & 2.760 & .001 \\
\cline { 2 - 7 } & $\begin{array}{l}\text { Similarities } \\
\text { Test }\end{array}$ & $118.244 \mathrm{~b}$ & 12 & 9.854 & 1.405 & .163 \\
\cline { 2 - 7 } & Numerical Test & $105.769 \mathrm{c}$ & 12 & 8.814 & 1.677 & .071 \\
\cline { 2 - 7 } & Trace Test & $138.532 \mathrm{~d}$ & 12 & 11.544 & 2.125 & .016 \\
\cline { 2 - 7 } & Total score & $1137.884 \mathrm{e}$ & 12 & 94.824 & 3.153 & .000 \\
\cline { 2 - 7 } & $\begin{array}{l}\text { Knowledge } \\
\text { Test }\end{array}$ & $4934.211 \mathrm{f}$ & 12 & 411.184 & 2.093 & .018 \\
\cline { 2 - 7 } & $\begin{array}{l}\text { Socio-Emotio- } \\
\text { anal Q }\end{array}$ & $705.876 \mathrm{~g}$ & 12 & 58.823 & 1.796 & .049 \\
\cline { 2 - 7 } & $\begin{array}{l}\text { Goodenough's } \\
\text { Drow a Man }\end{array}$ & $9958.033 \mathrm{~h}$ & 12 & 829.836 & 3.270 & .000 \\
\hline \multirow{5}{*}{ Intercept } & Difference Test & 2727.600 & 1 & 2727.600 & 354.975 & .000 \\
\hline \multirow{5}{*}{} & $\begin{array}{l}\text { Similarities } \\
\text { Test }\end{array}$ & 2118.042 & 1 & 2118.042 & 301.958 & .000 \\
\cline { 2 - 7 } & Numerical Test & 2239.989 & 1 & 2239.989 & 426.217 & .000 \\
\cline { 2 - 7 } & Trace Test & 3385.389 & 1 & 3385.389 & 623.224 & .000 \\
\cline { 2 - 7 } & Total score & 21151.703 & 1 & 21151.703 & 703.390 & .000 \\
\hline
\end{tabular}




\section{A. Hasanagić}

\begin{tabular}{|c|c|c|c|c|c|c|}
\hline & $\begin{array}{l}\text { Knowledge } \\
\text { Test }\end{array}$ & 36111.050 & 1 & 36111.050 & 183.827 & .000 \\
\hline & $\begin{array}{l}\text { Socio-Emotio- } \\
\text { anal Q }\end{array}$ & 12789.662 & 1 & 12789.662 & 390.410 & .000 \\
\hline & $\begin{array}{l}\text { Goodenough's } \\
\text { Drow a Man }\end{array}$ & 750110.440 & 1 & 750110.440 & 2955.630 & .000 \\
\hline \multirow{8}{*}{$\begin{array}{l}\text { Fathers'sEduc- } \\
\text { at-ional level }\end{array}$} & Difference Test & 8.495 & 3 & 2.832 & .369 & .776 \\
\hline & $\begin{array}{l}\text { Similarities } \\
\text { Test }\end{array}$ & .865 & 3 & .288 & .041 & .989 \\
\hline & Numerical Test & 20.327 & 3 & 6.776 & 1.289 & .278 \\
\hline & Trace Test & 47.301 & 3 & 15.767 & 2.903 & .035 \\
\hline & Total score & 57.688 & 3 & 19.229 & .639 & .590 \\
\hline & $\begin{array}{l}\text { Knowledge } \\
\text { Test }\end{array}$ & 1249.956 & 3 & 416.652 & 2.121 & .098 \\
\hline & $\begin{array}{l}\text { Socio-Emotio- } \\
\text { anal Q }\end{array}$ & 249.131 & 3 & 83.044 & 2.535 & .057 \\
\hline & $\begin{array}{l}\text { Goodenough's } \\
\text { Drow a Man }\end{array}$ & 1332.692 & 3 & 444.231 & 1.750 & .157 \\
\hline \multirow{8}{*}{$\begin{array}{l}\text { Mother's educ- } \\
\text { at-ional level }\end{array}$} & Difference Test & 59.696 & 3 & 19.899 & 2.590 & .053 \\
\hline & $\begin{array}{l}\text { Similarities } \\
\text { Test }\end{array}$ & 25.983 & 3 & 8.661 & 1.235 & .297 \\
\hline & Numerical Test & 11.776 & 3 & 3.925 & .747 & .525 \\
\hline & Trace Test & 13.736 & 3 & 4.579 & .843 & .471 \\
\hline & Total score & 164.775 & 3 & 54.925 & 1.827 & .143 \\
\hline & $\begin{array}{l}\text { Knowledge } \\
\text { Test }\end{array}$ & 350.882 & 3 & 116.961 & .595 & .618 \\
\hline & $\begin{array}{l}\text { Socio-Emotio- } \\
\text { anal Q }\end{array}$ & 76.091 & 3 & 25.364 & .774 & .509 \\
\hline & $\begin{array}{l}\text { Goodenough's } \\
\text { Drow a Man }\end{array}$ & 1391.940 & 3 & 463.980 & 1.828 & .142 \\
\hline \multirow{8}{*}{$\begin{array}{l}\text { Father's educ- } \\
\text { at-ional level } \\
{ }^{*} \text { Mother's } \\
\text { educat-ional } \\
\text { level }\end{array}$} & Difference Test & 11.093 & 6 & 1.849 & .241 & .963 \\
\hline & $\begin{array}{l}\text { Similarities } \\
\text { Test }\end{array}$ & 39.461 & 6 & 6.577 & .938 & .468 \\
\hline & Numerical Test & 8.164 & 6 & 1.361 & .259 & .955 \\
\hline & Trace Test & 69.952 & 6 & 11.659 & 2.146 & .048 \\
\hline & Total score & 108.901 & 6 & 18.150 & .604 & .727 \\
\hline & $\begin{array}{l}\text { Knowledge } \\
\text { Test }\end{array}$ & 431.362 & 6 & 71.894 & .366 & .900 \\
\hline & $\begin{array}{l}\text { Socio-Emotio- } \\
\text { anal Q }\end{array}$ & 419.485 & 6 & 69.914 & 2.134 & .050 \\
\hline & $\begin{array}{l}\text { Goodenough's } \\
\text { Drow a Man }\end{array}$ & 703.113 & 6 & 117.186 & .462 & .836 \\
\hline \multirow[t]{3}{*}{ Error } & Difference Test & 2120.761 & 276 & 7.684 & & \\
\hline & $\begin{array}{l}\text { Similarities } \\
\text { Test }\end{array}$ & 1935.964 & 276 & 7.014 & & \\
\hline & Numerical Test & 1450.522 & 276 & 5.256 & & \\
\hline
\end{tabular}


Socioeconomic Status of Parents and the Achievement of Children on Readiness for School Tests

\begin{tabular}{|c|c|c|c|c|c|c|}
\hline & Trace Test & 1499.247 & 276 & 5.432 & & \\
\hline & Total score & 8299.618 & 276 & 30.071 & & \\
\hline & $\begin{array}{l}\text { Knowledge } \\
\text { Test }\end{array}$ & 54217.546 & 276 & 196.440 & & \\
\hline & $\begin{array}{l}\text { Socio-Emotio- } \\
\text { anal Q }\end{array}$ & 9041.639 & 276 & 32.760 & & \\
\hline & $\begin{array}{l}\text { Goodenough's } \\
\text { Drow a Man }\end{array}$ & 70046.147 & 276 & 253.790 & & \\
\hline Total & Difference Test & 12387.000 & 289 & & & \\
\hline & $\begin{array}{l}\text { Similarities } \\
\text { Test }\end{array}$ & 10758.000 & 289 & & & \\
\hline & Numerical Test & 10761.000 & 289 & & & \\
\hline & Trace Test & 11946.000 & 289 & & & \\
\hline & Total score & 93367.000 & 289 & & & \\
\hline & $\begin{array}{l}\text { Knowledge } \\
\text { Test }\end{array}$ & 209422.000 & 289 & & & \\
\hline & $\begin{array}{l}\text { Socio-Emotio- } \\
\text { anal Q }\end{array}$ & 65388.000 & 289 & & & \\
\hline & $\begin{array}{l}\text { Goodenough's } \\
\text { Drow a Man }\end{array}$ & 2772113.000 & 289 & & & \\
\hline Correct-ed & Difference Test & 2375.232 & 288 & & & \\
\hline Total & $\begin{array}{l}\text { Similarities } \\
\text { Test }\end{array}$ & 2054.208 & 288 & & & \\
\hline & Numerical Test & 1556.291 & 288 & & & \\
\hline & Trace Test & 1637.779 & 288 & & & \\
\hline & Total score & 9437.502 & 288 & & & \\
\hline & $\begin{array}{l}\text { Knowledge } \\
\text { Test }\end{array}$ & 59151.758 & 288 & & & \\
\hline & $\begin{array}{l}\text { Socio-Emotio- } \\
\text { anal Q }\end{array}$ & 9747.516 & 288 & & & \\
\hline & $\begin{array}{l}\text { Goodenough's } \\
\text { Drow a Man }\end{array}$ & 80004.180 & 288 & & & \\
\hline
\end{tabular}

a. R Squared $=.107$ (Adjusted R Squared $=.068$ )

b. $\mathrm{R}$ Squared $=.058$ (Adjusted R Squared $=.017$ )

c. R Squared $=.068$ (Adjusted R Squared $=.027$ )

$\mathrm{d}$. $\mathrm{R}$ Squared $=.085$ (Adjusted R Squared $=.045$ )

e. $\mathrm{R}$ Squared $=.121$ (Adjusted R Squared $=.082)$

f. $\mathrm{R}$ Squared $=.083$ (Adjusted R Squared $=.044$ )

g. $\mathrm{R}$ Squared $=.072($ Adjusted R Squared $=.032)$

h. R Squared $=.124$ (Adjusted R Squared $=.086$ ) 


\section{A. Hasanagić}

Table 3 shows statistically significant differences in term of interaction appeared for Differences Test, Trace Test, Total score and Socio-Emotional maturity Questionnaire, and Goodenough's "Draw a Man" Test. Particularly educational level of father is important factor for Trace Test, while the other results in this manner were not statistically significant. Because of that one way ANOVA was done, which showed statistically significant differences in term that children whose fathers are more educated (first or second University level) had better results that children whose fathers are not that educated. Also C coefficient of correlation was done (table 4), and it showed that there is statistically significant correlation between the level of education of fathers and success of their children on Readiness for School Tests. The correlation was not significant only on Goodenough "Draw-a-man" test. The One way ANOVA for educational level of mothers showed statistical significant differences between children whose mothers have finished only elementary school, compared to children whose mothers finished high school and university level. Also there is a correlation between level of education of mothers and success in Differences test, Similarity test, Numerical test, Total score and Knowledge test. The same significance was shown by one way ANOVA.

Table 4. C coefficient values between level of education of parents and dependent variables

\begin{tabular}{|l|l|l|l|l|}
\hline \multirow{2}{*}{} & \multicolumn{2}{|c|}{ Educational level of father } & \multicolumn{2}{c|}{ Educational level of mother } \\
\cline { 2 - 5 } & C-coefficient & Sig. & C-coefficient & Sig. \\
\hline Differences Test &, 383 &, 049 &, 383 &, 046 \\
\hline Similarities Test &, 373 &, 043 &, 372 &, 048 \\
\hline Numerical Test &, 385 &, 004 &, 327 &, 035 \\
\hline Trace Test &, 352 &, 043 &, 315 &, 346 \\
\hline Total &, 484 &, 041 &, 524 &, 038 \\
\hline Knowledge Test &, 611 &, 048 &, 635 &, 002 \\
\hline $\begin{array}{l}\text { Socio-emotional } \\
\text { IQ. }\end{array}$ &, 428 &, 025 &, 368 &, 431 \\
\hline Goodenough's &, 676 &, 067 &, 670 &, 104 \\
\hline
\end{tabular}

Table5. T-testforbigindependentsamplesfortestingdifferencesbetweenchildrenfromurbanandruralareas

\begin{tabular}{|c|c|c|c|c|c|c|c|}
\hline & \multirow{2}{*}{$\begin{array}{l}\text { Leven's test } \\
\mathrm{F}\end{array}$} & \multicolumn{6}{|l|}{ t-test } \\
\hline & & Sig. & $\mathrm{t}$ & Df & $\begin{array}{l}\text { Sig. two } \\
\text { tailed }\end{array}$ & $\begin{array}{l}\text { Difference } \\
\text { M }\end{array}$ & St. error \\
\hline $\begin{array}{l}\text { Differences } \\
\text { Test }\end{array}$ & 2,683 &, 102 & ,638 & 294 &, 524 & ,211 & ,331 \\
\hline $\begin{array}{l}\text { Similarities } \\
\text { Test }\end{array}$ &, 525 & ,469 & 4,047 & 294 &, 000 & 1,230 & ,304 \\
\hline
\end{tabular}




\begin{tabular}{|l|l|l|l|l|l|l|l|}
\hline $\begin{array}{l}\text { Numerical } \\
\text { Test }\end{array}$ & 2,422 &, 121 & $-1,160$ & 294 &, 247 &,- 313 &, 270 \\
\hline Trace Test & 2,670 &, 103 & $-1,422$ & 294 &, 156 &,- 398 &, 280 \\
\hline Total & 5,133 &, 024 &, 918 & 294 &, 359 &, 732 &, 797 \\
\hline $\begin{array}{l}\text { Knowledge } \\
\text { Test }\end{array}$ & 3,271 &, 072 &,- 673 & 294 &, 502 & $-1,121$ & 1,667 \\
\hline $\begin{array}{l}\text { So- } \\
\text { cio-emo- } \\
\text { tional Q }\end{array}$ &, 443 &, 506 &,- 135 & 294 &, 893 &,- 092 &, 682 \\
\hline $\begin{array}{l}\text { Goode- } \\
\text { nough's }\end{array}$ & 2,750 &, 098 & 4,020 & 294 &, 000 & 7,623 & 1,896 \\
\hline & & & & & & & \\
\hline
\end{tabular}

The T-test for big independent samples showed that there are no statistically significant differences between children from urban and rural areas in all subtests but Similarity test, where children from town had statistically significant higher scores, as well as in Goodenough "Draw-a-man" test.

\section{Discussion}

Since the beginning of measuring the intelligence, it has been shown that there are some statistically significant differences between different ethnical groups, or socio-economical groups. At first, those differences were observed in term on differences between races, but further research showed the importance of socio-economic status as an independent variable on educational achievement. Arthur Jensen (1969) tried to show how unsuccessful compensatory programs which were organized for low socio-economic status children (mostly black population) actually were, with conclusion that there is no such program that can compensate low genetic potential. Similar conclusions were found by Herrnstein and Murray's (1994) where they claim about advantages of white nation in intellectual potential.

These attitudes were pretty controversial, and we can find a lot of scientific evidences that go against these statements. In that term Sternberg (according to Zarevski, 2000) states a lot of research findings in which it is approved that differences between white and black population are not result of different genetic potential, but rather because they are result of different socio-economic status. Whites and blacks from the same socio-economic group will have the similar results on intellectual abilities tests.

Many researches as a result have significant correlation between socio-demographic variables and academic achievement. Socio-economic status is often determined as an educational background of parents or income of family. 'A family's socioeconomic status is based on family income, parental education level, paren- 
tal occupation, and social status in the community (such as contacts within the community, group associations, and the community's perception of the family)', note Demarest, Reisner, Anderson, Humphrey, Farquhar, and Stein (1993). Families with higher socio-economic status are more successful in preparation of their children for school, usually because they have more resources for encouraging and support of child development. They can provide good environment for their children, and they seek for information how to provide all of benefits for their children.

Families with low socio-economic status often have the lack of social, financial and economic support. They do not have adequate approach to resources which provide the support to child development, as well as to information which will help them to encourage their children in terms of better preparation for school.

Similar research findings like Rothenberg's who had discovered obvious differences in conservation of number between children of different socio-economic status (education of parents), lead us to conclusion that education of parents and differences in socioeconomic status lead to differences in cognitive abilities of children even at the preschool age, and also on academic achievement. Those differences are hardly to compensate after they start with school.

Vlahović-Stetić, et. al, found correlation between educational level of parents and achievement of their children on Readiness for school tests from 0,17 to 0,22 , and those coefficients are interpreted as better family environment can result with better readiness for school. Tovilović and Baucal (2007) put the special accent on children from marginalized population which is highly deprived in socio-economic meaning.

Sirin (2003) did and meta-analysis of all research conducted from 1990 till 2000 year. In more than 50 studies there were statistically significant correlations between SES and school achievement, in which average correlation is 0,29. Horvat (1986) also claims that there is correlation between SES of family and child development, in term that children from better socio-economic status have better results in all questions including Piaget's examples.

Results from this research also show that socio-economic status is important factor of achievement of a child on Readiness for school tests. In this research, educational level of parents (mother and father) observing like interaction model, is important factor for achievement in Difference Test, Trace Test, Total Score, Knowledge Test, Social-emotional Questionnaire and Goodenogh's Draw a Man Test. 
Also our one way ANOVA, considering the father's educational level showed statistically significant differences in all dependent variables, as well as mother's educational level (figures 1 and 2).

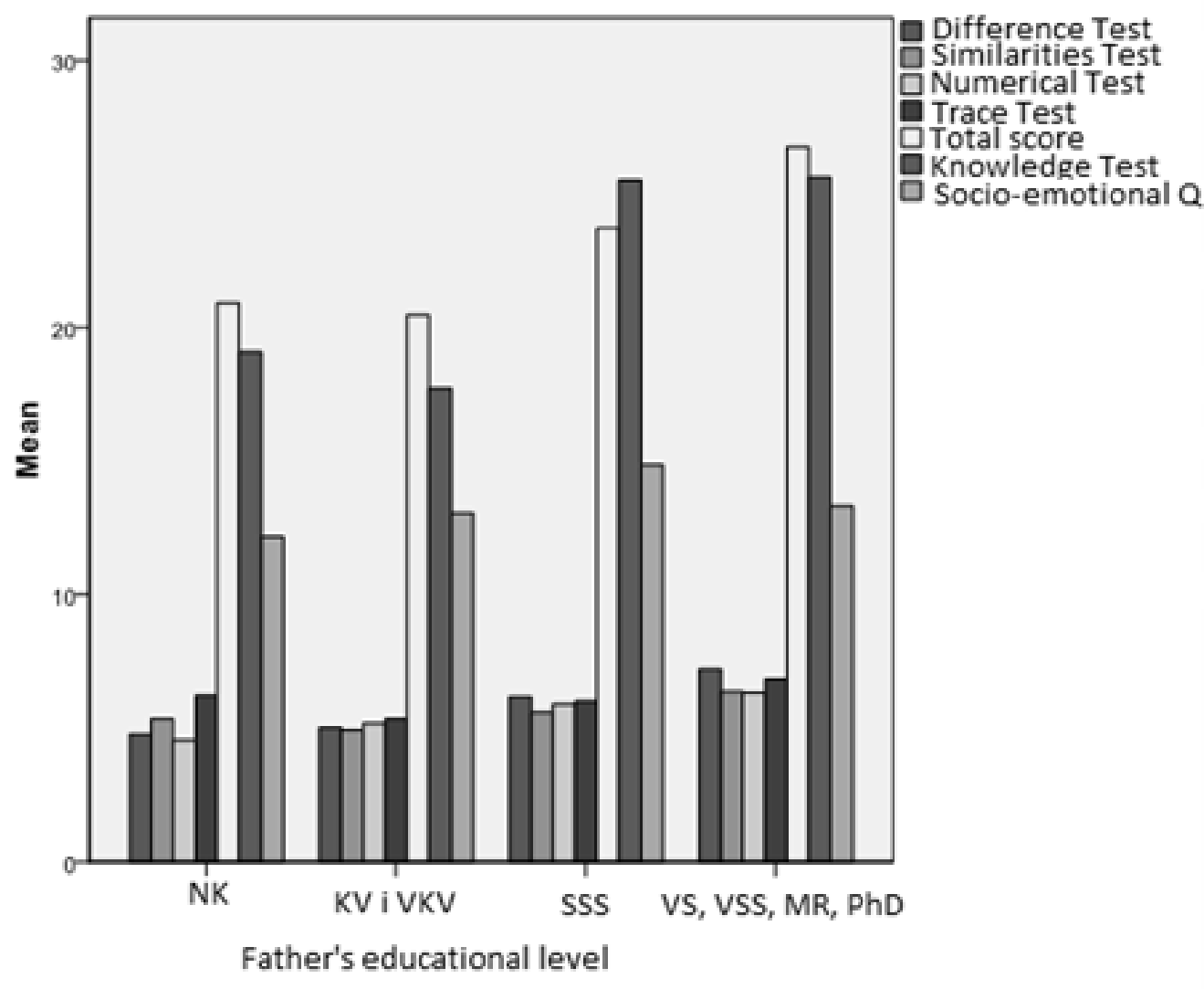

Figure 1. Graph of Means of all statistically significant variables in term of father's educational level.

Fathers who finished high school or university level are more able to provide better environment for children development compared with fathers without school, or only elementary school or vocational school. Level of education of mothers showed as important factor too, in determining readiness for school of children. Differences appeared between children from different socio-economic levels on Difference Test, Similarity Test, Numerical Test, Total result, Knowledge Test, and Goodenough's "Draw a Man Test," and post-hoc test showed that those differences are mainly in direction that more educated mothers (high school and university level) provide more supportive environment for child development than less educated mothers (no elementary school, elementary school and vocational school). (Figure 2) 


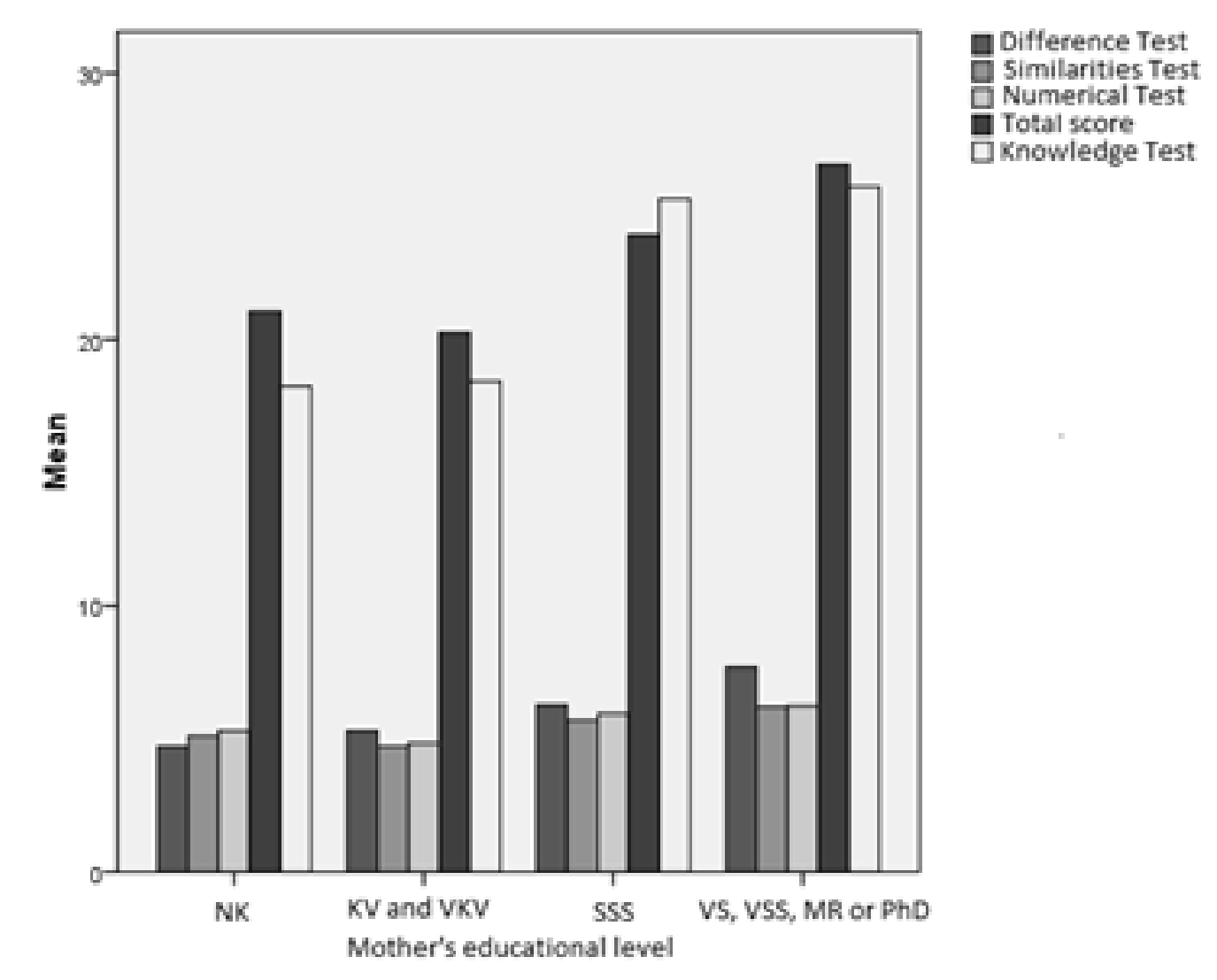

According to Crnic and Lamberty (1994)

The segregating nature of social class, ethnicity, and race may well reduce the variety of enriching experiences thought to be prerequisite for creating readiness to learn among children. Social class, ethnicity, and race entail a set of "contextual givens" that dictate neighborhood, housing, and access to resources that affect enrichment or deprivation as well as the acquisition of specific value systems.

Ramey and Ramey (1994) describe the relationship of family socioeconomic status to children's readiness for school:

Families with low socioeconomic status often lack the financial, social, and educational supports that characterize families with high socioeconomic status. Poor families also may have inadequate or limited access to community resources that promote and support children's development and school readiness. Parents may have inadequate skills for such activities as reading to and with their children, and they may lack information about childhood immunizations and nutrition. 
We conclude that socio-economic status is an important factor for determining readiness for school of children when it is operationally defined like parent's educational level. This conclusion should have help teachers and other educational professionals when working with children to provide better insight into environmental factors before making diagnosis. Children from different socio-economic statuses cannot be observed from the same point of view and professionals need to give them a help and to encouragetheirdevelopmentwhich wasdeprivedbecauseoftheenvironmentalfactors.

Sometimes as socio-economic variable cultural differences are observed, and so another question from this research was about differences between children form urban and rural areas. Cultural differences can be different and they differ from society to society. In historical perspective of this topic, it is important to mention, that all until now, different standards were used in evaluation of readiness for school of children from urban and rural areas. Different standards were used, because it was scientifically proven that there were differences between children from urban and rural areas. Gajanović i Mandić (1982) found that there are statistically significant differences between children from town and from village and in that way they provided different standards for measuring readiness for school of children. Those differences were not differences in intellectual or cognitive functioning, but they were a product of different environment, in term that children from rural areas, because they grow up differently had the lack of knowledge, academic skills, and socio-communicational skills, but they were better in physical skills.

This research did not show statistically significant differences on most of the subtests between village and town children. Statistically significant differences appeared only on Similarity test and on Goodenough's "Draw a Man" test. In Bosnia village life has significantly changed in recent decades. People in rural areas have more opportunities to educate themselves and to work better jobs than ever before. Globalization has leveled the playing field in terms of technological access between cities and villages; regardless of where one resides, they will still have access to educational and technological opportunities in ways previously unimaginable.

Bosnia and Herzegovina is similar to many other developing countries in terms of educational achievement over the past few decades; children from villages more often go to university than thirty years ago. Previously, females were finishing elementary school and only some of them went to high school. Males usually were finishing vocationalschooland started to work. Now, females and malesfrom villagesgo to university.

45 Years ago, Toličić (1970) found differences between urban and rural children in educational achievement in Yugoslavia. Here we could make and as- 
sumption that before the war in area of ex-Yugoslavia, there were some differences, but after the war those differences disappeared or because of the migration of population, or because of the globalization, or because of the education of youth from villages, or all of those factors together caused those results and conclusions. Due to these results, it is not valid anymore to use different standards in evaluation of readiness for school of children from villages, and from towns, same standards should be used, as the same expectations as well.

\section{Conclusions:}

1. The Educational level of parents is an important factor in determining achievement of a child on Readiness for school tests. Higher educated parents provide more stimulus for their children, resulting in those children have higher result on these tests. Level of education of parents should be considered when working with children. Teachers and professionals should make even greater efforts to provide an welcoming atmosphere for children who came from more interllectually deprived environment. 2. Socio-demographic characteristics are not important factors in determining achievement of child on readiness for school tests. Most of the independent variables tested in this study showed that there were few statistically significant differences between children from urban and rural areas. Teachers and professionals who work with children should have this in mind; children from rural and urban areas should be approached in the same objective, open-minded manner and be given equal opportunities for educational success.

\section{References:}

Adžibaba-Gajanović N. (1982.), Psihički razvoj djeteta i vaspitanje, Svjetlost, Sarajevo Albrow M. \& King E. (1990) Globalization, knowledge, and society, Sage Publications, Buggle F. (2002.), Razvojna psihologija Jeana Piageta, Naklada Slap, Jastrebarsko Bukvić, A. (1980), Predviđanje uspeha u školi, "Psihologija" br. 4, Beograd Crnic, K., \& Lamberty G. (1994). Reconsidering school readiness: Conceptual and applied perspectives. Early Education and Development 5(2), 99-105. Available online http://readyweb.crc.uiuc. edu/library/1994/crnic1.html

Ćehić E. (1997.), Indikatori zrelosti djece za polazak u školu, Psihoteka, Sarajevo, Demarest, E.J., Reisner, E.R., Anderson, L.M., Humphrey, D.C., Farquhar, E., \& Stein, S.E. (1993). Review of research on achieving the nation's readiness goal. Washington, DC: U.S. Department of Education. [Online]. Available: (http://www.ncrel.org/sdrs/areas/issues/students/earlycld/ea7lk5. htm)

Demetriou A., Doise W. I Van Lieshout C. (1998), Life-span developmental psychology, John Wiley \& Sons, West Sussex,

Duncan G., Claessens A., Huston A.C., Pagani L.S., Engel M., Sexton H., Dowsett Ch.J., Magnuson K., Klebanov P., Feinstein L., Gunn B.J., Duckworth K., Japel C. (2007.), School readiness and later achievement, Developmental psychology, Vol. 43. No. 6. 1428-1446. 
Duran M. (1995.), Dijete i igra, Naklada Slap, Jastrebarsko,

Farrar E, Goldfeld S, Moore T. (2007.) School readiness, Children's Research Institute, Melbourne. Australia,

Ferenčić J, Keresteš G. I Bratko D. (2005.), Roditeljske implicitne teorije dječije inteligencije: razlike u funkciji spola i obrazovanja, Suvremena psihologija 8(2005),2, 147 - 161.

Furlan I. (1991.), Čovjekov psihički razvoj, Školska knjiga, Zagreb,

Gardner H., Kornhaber M.L. i Wake W.K. (1999.), Inteligencija, različita gledišta, Naklada Slap, Jastrebarsko,

Herrnstein, R. and Murray, Ch. (1994). The bell curve: intelligence and class structure in American life, New York: The Free Press,

Horvat L. (1986.), Predškolsko vaspitanje i intelektualni razvoj, Zavod za udžbenike i nastavna sredstva, Beograd,

Jan, M. (2009), Key Issues and Dimensions, Globalization of Media 29.1 : 66 - 75. EuroJournals Publishing, Inc. 2009.

Jensen A R. (1969).How much can we boost IQ and scholastic achievement? Harvard Educ. Rev. 39:1-123,

Klarin M. (2006.) Razvoj djece u socijalnom kontekstu, Naklada Slap, Jastrebarsko,

Mandić P. i Gajanović N. (1982.) Teorijske i praktične osnove upisa djece u školu - priručnik uz instrumentarij, Svjetlost, Sarajevo,

Mandić P. i Gajanović N. (1991.), Psihologija u službi učenja i nastave, Grafokomerc, Tunjić, Lukavac,

Papalia D. E. i Wendkos Olds S. (1998.) Human development, McGraw Hill, sedmo izdanje,

Piaget J. i Inherdel B. (1988.), Intelektualni razvoj djeteta, Zavod za udžbenike i nastavna sredstva,

Beograd,

Piaget J. i Inherdel B. (1990.), Psihologija deteta, Dobra vest, Novi Sad,

Ramey S.L. \& Ramey C.T. (1994). The transition to school: Why the first few years matter for a lifetime. Phi Delta Kappan, 76(30), 194-198.

Research brief, Child trends (2001.) School readiness: Helping communities get children ready for school and schools ready for children, Washington, DC

Research brief, The Initial Effect of Kindergarten Program Traits on StudentAchievement, March 30, 2004 | Volume 2 Number 7.

Seefeldt C \& Barbour N. (1994), Early Childhood Education, Macmillan Publishing Company, Englewood Cliffs, USA,

Sirin S. R.(2003.), The relationship between socioeconomic status and school outcomes: Meta analytic review of research, 1990--2000, Boston College Dissertations and Theses

Smiljanić Č.V. i Toličić I. (1976.), Dečja psihologija, Zavod za udžbenike i nastavna sredstva, Beograd,

Starc B., Obradović Č. M., Pleša A., Profaca B., Letica M. (2004.), Osobine i psihološki uvjeti razvoja djeteta predškolske dobi, Golden marketing, Zagreb,

Tovilović S. \& Baucal A. (2007.), Procena zrelosti za školu, Centar za primenjenu psihologiju,

Beograd,

Vasta R., Haith M.M., Miller S. (1998.) Dječija psihologija, Naklada Slap, Jastrebarsko,

Vlahović-Štetić V., Vizek-Vidović V., Arambašić L., Miharija Ž. (1995.) Priručnik za test spremnosti za školu, Naklada Slap, Jastrebarsko,

Zarevski P., (2000.), Struktura i priroda inteligencije, Naklada Slap, Jastrebarsko. 